\begin{abstract}
ARTIKEL
PENINGKATAN KEMAMPUAN PENALARAN MATEMATIKA MATERI TRIGONOMETRI MELALUI PENERAPAN MODEL PEMBELAJARAN DISCOVERY LEARNING DENGAN PENDEKATAN SAINTIFIK PADA KELAS X SMA NEGERI 11 MAKASSAR
\end{abstract}

IMPROVEMENT OF MATHEMATICS REASONING ABILITY IN TRIGONOMETRY MATERIAL THROUGH THE IMPLEMENTATION OF DISCOVERY LEARNING MODEL WITH SCIENTIFIC APPROACH OF CLASS X AT SMAN 11 MAKASSAR

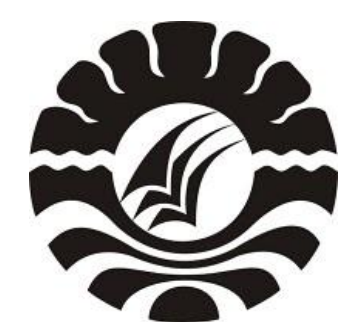

PROGRAM PASCASARJANA

UNIVERSITAS NEGERI MAKASSAR

2015 


\title{
PENINGKATAN KEMAMPUAN PENALARAN MATEMATIKA MATERI TRIGONOMETRI MELALUI PENERAPAN MODEL PEMBELAJARAN DISCOVERY LEARNING DENGAN PENDEKATAN SAINTIFIK PADA KELAS X SMA NEGERI 11 MAKASSAR
}

\author{
Habriah Ahmad, H. Hamzah Upu, Muh. Darwis
}

\begin{abstract}
ABSTRAK
Penelitian ini bertujuan untuk (1) mendeskripsikan proses pembelajaran matematika melalui penerapan Model Pembelajaran Discovery Learning dengan Pendekatan Saintifik pada materi trigonometri siswa kelas X SMA Negeri 11 Makassar, (2) meningkatkan kemampuan penalaran matematika siswa kelas X SMA Negeri 11 Makassar dengan Model Pembelajaran Discovery Learning dengan Pendekatan Saintifik pada materi trigonometri. Jenis penelitian ini adalah penelitian tindakan kelas, yang terdiri atas dua siklus dimana tiap siklus enam kali pertemuan yang melalui tahap perencanaan, pelaksanaan, pengamatan dan refleksi. Teknik pengumpulan data yang digunakan adalah observasi aktivitas guru dan siswa, pemberian angket respons siswa, dan tes kemampuan penalaran matematika disetiap akhir siklus. Subjek penelitian ini adalah siswa kelas X-7 SMA Negeri 11 Makassar yang berjumlah 38 orang. Penelitian ini dilakukan pada semester genap Tahun Pelajaran 2014/2015. Hasil penelitian ini menunjukkan bahwa (1) proses pembelajaran matematika melalui model pembelajaran discovery learning dengan pendekatan saintifik siswa kelas X SMA Negeri 11 Makassar mencapai keberhasilan yaitu aktivitas yang mendukung proses belajar mengajar terus mengalami peningkatan dan aktivitas yang tidak relevan dengan kegiatan proses belajar mengajar berkurang dari pertemuan ke pertemuan berikutnya, bahkan di akhir siklus II sudah tidak tampak aktivitas yang tidak relevan dengan kegiatan proses belajar mengajar, (2) penerapan model pembelajaran discovery learning dengan pendekatan saintifik dapat meningkatkan kemampuan penalaran siswa kelas X SMA Negeri 11 Makassar dalam pembelajaran matematika, hal ini terlihat dari hasil tes kemampuan penalaran matematika yang tergolong dalam kategori tinggi.
\end{abstract}

Kata Kunci : Discovery Learning, penalaran, pendekatan saintifik. 


\begin{abstract}
This research aimed at (1) describing the process of mathematics learning through the implementation of discovery learning with scientific approach in trigonometry material of class X students at SMAN 11 Makassar, (2) improving the students' mathematics reasoning ability of class $\mathrm{X}$ at SMAN 11 Makassar by using discovery learning model with scientific approach in trigonometry material. This is a classroom action research, which consisted of 2 cycles where each cycle consist of 6 (six) meetings by conducting the steps of planning, acting, observing, and reflecting. The data collecting techniques used were teachers and students' activities observation, students' response questionnaires, and mathematics reasoning ability test given at the end of each cycle. The subjects of this research were 38 people of class X-7 at SMAN 11 Makassar. This research was conducted in the first semester of 2014/2015 academic year. The results of the research show that (1) the process of mathematics learning through discovery learning with scientific approach of class $\mathrm{X}$ students at SMAN 11 Makassar is a success where the supporting teaching-learning activities is always improve and the non-relevant activities for teaching-learning process are decreased in each meeting, even at the end of cycle II there is no more non-relevant activities in the learning process, (2) the implementation of discovery learning model with scientific approach can improve the students' reasoning ability of class $\mathrm{X}$ at SMAN 11 Makassar in mathematics learning process, it can be seen from the test result of mathematics reasoning ability which can be categorized as high.
\end{abstract}

Keywords : discovery learning, reasoning, scientific approach. 


\section{Pendahuluan}

Penalaran merupakan suatu bentuk pemikiran, Hardjosatoto (Wulandari, 2011) mengatakan bahwa penalaran menjadi salah satu kejadian dari proses berfikir. Batasan mengenai berpikir (thinking) adalah serangkaian aktivitas mental yang banyak macamnya seperti mengingat kembali suatu hal, berkhayal, menghafal, menghitung, menghubungkan beberapa pengertian, menciptakan sesuatu konsep atau memperkirakan berbagai kemungkinan.

Salah satu model pembelajaran yang memberi kesempatan kepada siswa dalam mengembangkan dan menemukan pemahamannya sendiri sehingga belajar matematika menjadi bermakna, informasi-informasi yang disajikan mudah diserap, diproses dan disimpan dengan baik oleh sistem memori siswa serta memberikan kesempatan kepada siswa untuk lebih banyak berperan secara aktif didalam kelas adalah model pembelajaran penemuan (discovery learning).

Berdasarkan pengalaman peneliti dan rekan-rekan sesama guru matematika di SMA Negeri 11 dalam pembelajaran matematika siswa terkesan takut dan kurang percaya diri dalam mengemukakan ide atau jawabannya, serta siswa kurang bergairah menyelesaikan soal. Ketika guru meminta siswa untuk menyelesaikan soal, beberapa dari siswa kebingungan dan kesulitan dalam menyelesaikan soal tersebut, siswa telihat pasif dan siswa kurang komunikatif dalam kegiatan belajar mengajar. Terkadang masih ada siswa yang menunggu hasil pekerjaan dari temannya dan ada juga siswa merasa takut atau malu untuk menyelesaikan soal di depan temannya sendiri. Sebagian yang lain tidak dapat mengembangkan keterampilan menyelesaikan soal pada penyelesaian soal yang berbeda dari apa yang telah dipelajari. Dengan kata lain siswa tidak mampu menyelesaikan soal matematika yang lain yang berbeda dari apa yang telah dicontohkan. Sehingga kondisi ini menggambarkan rendahnya daya nalar siswa pada saat pembelajaran matematika di sekolah ini. Hal ini pun dibuktikan dengan rendahnya nilai rata-rata hasil belajar matematika siswa kelas X pada semester ganjil tahun pelajaran 2014/2015 yaitu 73,95 dari skor ideal 100 dengan simpangan baku 6,41. 
Rendahnya kemampuan penalaran ini juga terjadi pada saat mengajarkan materi trigonometri di kelas khususnya kelas X. Sebagian besar siswa kesulitan menerapkan rumus perbandingan trigonometri pada soal-soal yang memerlukan penalaran (utamanya soal-soal yang berbentuk soal cerita). Pada proses pembelajaran siswa seringkali mengalami kesulitan dalam menerapkan perbandingan sinus, cosinus, atau tangen sehingga dari permasalahan yang diberikan siswa terkadang tidak tahu ataupun salah menerapkan aturan sinus, cosinus atau tangen pada soal yang diberikan. Hal ini ditandai dengan rendahnya hasil tes kemampuan penalaran matematika siswa pada pra tindakan yaitu diperoleh skor rata-rata 42,17 dari skor ideal 100 dengan standar deviasi 4,45 termasuk kategori rendah.

Dari beberapa uraian diatas, guru dituntut untuk lebih kreatif dan profesional dalam memilih pendekatan pembelajaran yang sesuai dengan karakteristik siswa serta karakteristik materi yang akan diajarkan.. Proses pembelajaran harus lebih diarahkan pada apa yang harus dikuasai siswa dengan menggunakan pendekatan yang dapat mengaktifkan siswa. Sehingga menjadi alasan peneliti untuk menggunakan Model Pembelajaran Discovery Learning dengan pendekatan saintifik karena dengan model pembelajaran ini siswa lebih termotivasi untuk terlibat secara langsung, mengalami, menemukan solusi, dan terampil menyelesaikan masalah dari permasalahan yang sedang diamati, serta berdampak pada terciptanya situasi pembelajaran yang aktif, dan kreatif yang akibatnya siswa mampu mengembangkan kemampuan penalaran khususnya dalam menjawab soal matematika.

Berdasarkan latar belakang masalah yang telah dikemukakan di atas, maka rumusan masalah dalam penelitian ini adalah:

1. Bagaimana proses pembelajaran matematika materi trigonometri melalui penerapan model pembelajaran Discovery Learning dengan pendekatan saintifik pada siswa kelas X SMA Negeri 11 Makassar?

2. Apakah dengan menerapkan model pembelajaran Discovery Learning dengan pendekatan saintifik dapat meningkatkan kemampuan penalaran matematika pada materi Trigonometri siswa kelas X SMA Negeri 11 Makassar? 


\section{A. Kajian Pustaka}

\section{Pembelajaran Matematika}

Kata "matematika" berasal dari bahasa Yunani Kuno (máthèma), yang berarti pengkajian, pembelajaran, ilmu, yang ruang lingkupnya menyempit, dan arti teknisnya menjadi "pengkajian matematika", bahkan demikian juga pada zaman kuno. Kata sifatnya adalah (mathēmatikós), berkaitan dengan pengkajian, atau tekun belajar, yang lebih jauhnya berarti matematis. Secara khusus, (mathēmatik $\square$ tékhnē), di dalam bahasa Latin ars mathematica, berarti seni matematika (Wikipedia, 2011). Karakteristik matematika menurut Soedjadi (2007: 9) dapat dituliskan sebagai berikut:

1. Memiliki objek kajian abstrak

2. Bertumpu pada kesepakatan

3. Berpola pikir deduktif

4. Memiliki simbol yang kosong dari arti

5. Memperhatikan semesta pembicaraan

6. Konsisten dalam sistemnya.

\section{Kemampuan Penalaran Matematika}

Penalaran merupakan suatu bentuk pemikiran, menurut Hardjosatoto (Wulandari, 2011) mengatakan bahwa penalaran menjadi salah satu kejadian dari proses berfikir. Batasan mengenai berpikir (thinking) adalah serangkaian aktivitas mental yang banyak macamnya seperti mengingat kembali suatu hal, berkhayal, menghafal, menghitung, menghubungkan beberapa pengertian, menciptakan sesuatu konsep atau memperkirakan berbagai kemungkinan. Jadi dalam hal ini dapat dikatakan bahwa bernalar dan berfikir sangat berbeda, dalam penalaran dapat terjadi salah satu pemikiran, tetapi tidak semua berpikir merupakan penalaran. Soekadijo (Wulandari, 2011) membuat kronologi terjadinya penalaran. Aktivitas mental dimulai dari pengamatan indera atau observasi empirik. Proses itu di dalam pikiran menghasilkan sejumlah pengertian dan proposisi sekaligus. Berdasarkan pengamatanpengamatan indera yang sejenis pula. Proses tersebut yang disebut penalaran karena 
berdasarkan sejumlah proposisi yang diketahui atau dianggap benar kemudian digunakan untuk menyimpulkan sebuah proposisi baru yang sebelumnya tidak diketahui.

\section{Model Pembelajaran Discovery Learning}

Penemuan (discovery) merupakan suatu metode pembelajaran yang dikembangkan berdasarkan pandangan konstruktivisme. Model ini menekankan pentingnya pemahaman struktur atau ide-ide penting terhadap suatu disiplin ilmu, melalui keterlibatan siswa secara aktif dalam proses pembelajaran. Menurut Wilcox dalam Hosnan ( 2014), dalam pembelajaran dengan penemuan, siswa di dorong untuk belajar sebagian besar melalui keterlibatan aktif mereka sendiri dengan konsep-konsep dan prinsip-prinsip, dan guru mendorong siswa untuk memiliki pengalaman dan melakukan percobaan yang memungkinkan mereka menemukan prinsip-prinsip untuk diri mereka sendiri.

Menurut Westwood dalam Sani (2014), pembelajaran dengan model discovery learning akan efektif jika terjadi hal-hal berikut :

1. Proses belajar dibuat secara terstruktur dengan hati-hati.

2. Siswa memiliki pengetahuan dan keterampilan awal untuk belajar.

3. Guru memberikan dukungan yang dibutuhkan siswa untuk melaksanakan penyelidikan.

\section{Pendekatan Saintifik}

Menurut Hosnan (2014: 34) pendekatan saintifik adalah proses pembelajaran yang dirancang sedemikian rupa agar peserta didik secara aktif mengonstruk konsep, hukum atau prinsip melalui tahapan-tahapan mengamati (untuk mengidentifikasi atau menemukan masalah), merumuskan masalah, mengajukan atau merumuskan hipotesis, mengumpulkan data dengan berbagai teknik, menganalisis data, menarik kesimpulan dan mengomunikasikan konsep, hukum atau prinsip yang "ditemukan". Penerapan pendekatan saintifik dalam pembelajaran melibatkan keterampilan proses, 
seperti mengamati, mengklasifikasi, mengukur, meramalkan, menjelaskan, dan menyimpulkan

Adapun bentuk kegiatan pembelajaran melalui pendekatan saintifik adalah sebagai berikut :
a) Mengamati (Observing)
b) Menanya (Questioning)
c) Mengumpulkan Informasi
d) Mengasosiasikan /Mengolah Informasi/menalar (associating)
e) Mengomunikasikan Pembelajaran

\section{Indikator Kemampuan Penalaran Siswa}

Sumarmo (Hudaedah, 2014: 361) memberikan indikator kemampuan yang termasuk pada kemampuan penalaran matematika yaitu : 1) menarik kesimpulan logis, 2) memberikan penjelasan terhadap model, fakta , sifat, hubungan atau pola, 3) memperkirakan jawaban dan proses solusi, 4) menggunakan pola hubungan untuk menganalisis situasi, atau membuat analogi, generalisasi, dan menyusun konjektur, 5) mengajukan lawan contoh, 6) mengikuti aturan inferensi, memeriksa validitas argument, membuktikan dan menyusun argument yang valid, dan 7) menyusun pembuktian langsung, tak langsung, dan pembuktian dengan induksi matematika.

Dalam penelitian ini untuk melihat penalaran siswa, digunakan karakteristik soal sesuai dengan indikator penalaran, yang meliputi :

1. Menyajikan pernyataan matematika secara lisan, tertulis, atau gambar

2. Mengajukan dugaan

3. Melakukan manipulasi matematika

4. Menyusun bukti dan memberikan alasan terhadap kebenaran solusi

5. Menarik kesimpulan dari pernyataan 


\section{B. Metode Penelitian}

\section{Jenis Penelitian}

Penelitian ini merupakan Penelitian Tindakan Kelas (Clasroom Action Research) yang direncanakan dilaksanakan secara bersiklus dan tiap siklus terdiri dari minimal 6 kali pertemuan, tiap pertemuan dilaksanakan selama 2 jam pelajaran. Tiap siklus meliputi 4 tahap, yaitu (i) perencanaan, (ii) tindakan, (iii) observasi dan evaluasi, serta (iv) refleksi.

\section{Subjek Penelitian}

Subjek penelitian tindakan kelas ini adalah semua siswa kelas X-7 SMA Negeri 11 Makassar. Jumlah siswa adalah 38 orang yang terdiri dari 17 siswa laki-laki dan 21 siswa perempuan.

\section{Waktu dan Tempat Penelitian}

1. Waktu Penelitian

Penelitian ini dilakukan pada semester genap tahun pelajaran 2014-2015 yang berlangsung pada tahun 2015. Penelitian ini terdiri dari 2 siklus dengan masing-masing siklus membutuhkan minimal 6 kali pertemuan.

2. Tempat penelitian

Penelitian ini dilakukan di SMA Negeri 11 Makassar, kelurahan Bongayya, kecamatan Tamalate kota Makassar, provinsi Sulawesi Selatan.

\section{Faktor-Faktor yang Diselidiki}

Untuk memperoleh data yang diperlukan dalam penelitian ini, maka faktor yang ingin diselidiki meliputi:

1. Faktor Input

Faktor input yang dimaksudkan dalam penelitian ini adalah hasil observasi awal mengenai siswa, guru, materi pelajaran, dan model, pedekatan ataupun strategi yang digunakan selama ini. 


\section{Faktor Proses}

Faktor proses yang dimaksudkan di dalam penelitian ini adalah hal-hal yang berkaitan dengan kemampuan penalaran yang meliputi 1) Menyajikan pernyataan matematika secara lisan, tertulis, atau gambar; 2) Mengajukan dugaan; 3) Melakukan manipulasi matematika; 4) Menyusun bukti dan memberikan alasan terhadap kebenaran solusi; 5) Menarik kesimpulan dari pernyataan pada subyek penelitian pada saat pelaksanaan tahap tindakan yang dipilih, yakni pada saat peneliti/guru menerapkan model pembelajaran discovery learning dengan pendekatan saintifik dalam pembelajaran matematika pada siswa kelas X-7 SMA Negeri 11 Makassar.

\section{Faktor Output}

Faktor output yang dimaksudkan di dalam penelitian ini yaitu kemampuan penalaran yang dicapai siswa setelah pelaksanaan tindakan pada sejumlah pertemuan dalam beberapa siklus.

\section{Prosedur Penelitian}

Prosedur atau langkah-langkah tindakan meliputi kegiatan perencanaan (planning), tindakan (acting), pengamatan (observing), dan refleksi (reflecting) untuk setiap siklus.

\section{Siklus I}

Pada pelaksanaan tindakan siklus I dilakukan kegiatan-kegiatan sebagai berikut :
a. Tahap Perencanaan Tindakan
b. Tahap Pelaksanaan Tindakan
c. Tahap Observasi
d. Tahap Refleksi

Hasil analisis siklus I menjadi acuan peneliti untuk merencanakan siklus II, sehingga hasil yang dicapai pada siklus berikutnya sesuai dengan yang diharapkan dan hendaknya bisa lebih baik dari siklus sebelumnya. 


\section{Siklus II}

Langkah-langkah yang dilakukan pada siklus II relatif sama dengan perencanaan dan pelaksanaan dalam siklus I dengan mengadakan perbaikan atau penambahan sesuai dengan kenyataan yang ditemukan di lapangan pada tahap siklus I. Tahap-tahap tindakan pada siklus II sama dengan siklus I yaitu : tahap perencanaan, tahap pelaksanaan, tahap observasi dan tahap refleksi.

Refleksi merupakan analisis kemampuan penalaran matematika dan angket respons siswa dari tahapan-tahapan siklus II. Data yang diperoleh dari tahap observasi dikumpulkan dan dianalisis, baik secara kuantitatif maupun kualitatif. Hasil analisis siklus II menjadi acuan peneliti untuk membuat kesimpulan dengan memperhatikan hasil yang diperoleh pada siklus I.

\section{Instrumen Penelitian}

Instrumen yang digunakan untuk mengumpulkan data adalah lembar observasi aktivitas siswa, lembar observasi aktivitas guru, angket respons siswa, dan tes kemampuan penalaran matematika.

\section{Teknik Pengumpulan Data}

Teknik pengumpulan data yang dilakukan dalam penelitian ini adalah sebagai berikut:

1. Data tentang Proses Pembelajaran

2. Data tentang Hasil Belajar

\section{Validasi Perangkat Pembelajaran dan Lembar Instrumen}

Perangkat pembelajaran dan instrumen penelitian dapat digunakan dalam penelitian apabila sudah divalidasi oleh para ahli.

a. Hasil Validasi Perangkat Pembelajaran

Adapun hasil validasi perangkat pembelajaran tersebut adalah :

a) Lembar kegiatan siswa (LKS)

b) Rencana Pelaksanaan Pembelajaran 
b. Hasil Validasi Instrumen Penelitian

Adapun hasil validasi instrumen penelitian tersebut adalah :

a) Tes Kemampuan Penalaran

b) Lembar Observasi Aktivitas Siswa (LOAS)

c) Lembar Observasi Aktivitas Guru Dalam Pembelajaran

d) Angket Respons Siswa (ARS)

\section{Teknik Analisis Data}

Pada penelitian ini digunakan dua macam analisis data yaitu analisis deskriptif kualitatif dan analisis deskriptif kuantitatif.

1. Analisis data dengan pendekatan kuantitatif deskriptif untuk memberikan gambaran mengenai tes hasil belajar siswa di setiap akhir siklus penelitian.

2. Analisis data dengan pendekatan kualitatif deskriptif untuk memberikan gambaran mengenai aktivitas siswa dan aktivitas guru dalam proses pembelajaran.

\section{Indikator Keberhasilan}

Adapun indikator keberhasilan di dalam penelitian ini adalah:

1. Rata-rata skor tes hasil belajar matematika siswa yang meliputi kemampuan penalaran, meningkat dari sebelum pembelajaran dan setiap siklus dengan ketentuan ketuntasan belajar tercapai, yaitu dengan standar kriterian ketuntasan belajar minimal (KKM) sebagaimana yang digunakan pada siswa SMA Negeri 11 Makassar untuk siswa kelas X adalah 85\% siswa mencapai skor minimal 75 dengan skor ideal 100.

2. Respons positif siswa terhadap pembelajaran matematika dengan menerapkan model pembelajaran discovery learning dengan pendekatan saintifik adalah lebih dari $50 \%$ siswa yang direspon, memberikan respons positif terhadap minimal 70\% jumlah aspek yang ditanyakan.

3. Data observasi dilihat dari kualitas proses pembelajaran yang meningkatnya keaktifan siswa yaitu berupa keaktifan individu maupun sosial dalam pembelajaran dan data observasi mengenai keterlaksanaan proses pembelajaran 
yaitu berupa keaktifan guru. Skor rata-rata aktivitas siswa dalam proses pembelajaran $\geq 2,5$ yang diambil dengan menggunakan lembar observasi aktivitas siswa dan skor rata-rata kemampuan guru dalam kegiatan pembelajaran dengan menggunakan model pembelajaran discovery learning dengan pendekatan saintifik $\geq 2,5$.

\section{Hasil Penelitian dan Pembahasan}

Penelitian tindakan ini dilaksanakan sebanyak 2 siklus. Siklus I dan siklus II dilaksanakan masing-masing selama 6 kali pertemuan. Pelaksanaan siklus II pada penelitian ini sebagai perbaikan siklus I. Penelitian ini menerapkan pembelajaran dengan menggunakan model pembelajaran discovery learning dengan pendekatan saintifik dengan mengobservasi aktivitas siswa, aktivitas guru dalam mengelola pembelajaran, hasil tes kemampuan panalaran matematika, dan respons siswa.

a. Pra tindakan

Hasil tes kemampuan penalaran matematika yang dilakukan pada pra tindakan dari 38 siswa yang menjadi subyek penelitian, dengan skor rata-rata kemampuan penalaran matematika pada pra tindakan ini adalah 42,17 dari skor ideal 100 dengan simpangan baku 4,45 termasuk kategori rendah. Dari hasil penelitian pada pra tindakan, maka dapat diketahui bahwa kemampuan penalaran matematika kelas X-7 SMA Negeri 11 Makassar masih tergolong rendah.

Berdasarkan hasil kemampuan penalaran matematika masih rendah, karena pembelajaran pada pra tindakan ini masih didominasi guru dengan model pembelajaran langsung dan masih bersifat konvensional dalam menyajikan bahan pelajaran, tanpa memperhatikan peserta didik secara individual. Yang lainnya mungkin disebabkan oleh faktor kecepatan guru mengajar dikarenakan untuk penyelesaian materi berdasarkan kurikulum tanpa memperhatikan kemampuan siswa menerima pelajaran dengan banyak materi yang dikuasai, siswa sebagaian saja yang menguasai materi pembelajaran tersebut. 


\section{b. Siklus I}

Hasil observasi terhadap kemampuan guru dalam mengelola pembelajaran model discovery learning dengan pendekatan saintifik pada materi perbandingan trigonometri pada siklus I diperoleh rata-rata aspek pembelajaran yang dilaksanakan dengan baik. Rata-rata aspek pada siklus I sebesar 3,46 dari skor ideal 5 dengan kategori baik. Namun ada beberapa hal yang harus diperbaiki pada siklus I, yaitu menyampaikan langkah-langkah pembelajaran, mengarahkan siswa untuk mencatat hasil pengamatannya dengan mengorganisasikan informasi.

Untuk hasil aktivitas siswa pada siklus I rata-rata nilainya 2,99 dari skor ideal 5 termasuk kategori cukup. Ada beberapa hal yang harus diperbaiki pada aktivitas siswa dalam pembelajaran pada siklus I, yaitu masih ada siswa yang tidak memperhatikan penjelasan guru dan tidak menuliskan tujuan pembelajaran yang akan dicapai, masih ada siswa tidak berpikir untuk memahami masalah yang diberikan pada LKS, masih ada siswa tidak bertanya mengenai hal-hal yang tidak jelas yang ada pada LKS, masih ada siswa tidak mencatat hasil pengamatannya dengan mengorganisasikan informasi, belum menemukan jawaban masalah secara mandiri dikelompoknya, masih ada siswa yang belum membandingkan dan mendiskusikan jawaban masalah dengan teman kelompoknya, masih ada siswa tidak berinteraksi secara maksimal dengan anggota lain dikelompoknya, masih kurang siswa yang menanggapi hasil presentasi kelompok lainya, masih kurang siswa yang melakukan generalisasi dan kesimpulan suatu masalah dari hasil diskusi, masih ada siswa tidak memperhatikan pembelajaran pada tahap refleksi, masih ada siswa tidak memperhatikan tugas yang diberikan guru,dan masih ada siswa tidak mendengarkan informasi guru untuk dipersiapkan di rumah pada materi selanjutnya. Disamping masalah diatas masih ada perilaku siswa yang tidak relevan dengan pembelajaran, yaitu mengganggu kegiatan siswa lainnya, berdiam diri ditempat duduknya tanpa berupaya menyelesaikan tugas yang diberikan, dan melakukan kegiatan yang lain yang tidak terkait dengan tugas yang diberikan. 
Hasil pengolahan tes kemampuan penalaran matematika dari pembelajaran pada siklus I skor rata-rata kemampuan penalaran matematika sebesar 70,23 dari skor ideal 100 dengan simpangan baku 10,75.

Berdasarkan uraian-uraian diatas mengenai aktivitas siswa, aktivitas guru, dan kemampuan penalaran matematika dalam pembelajaran dengan menerapkan model pembelajaran discovery learning dengan pendekatan saintifik, maka hal-hal yang perlu diperbaiki atau hal-hal yang mendukung model pembelajaran ini pada siklus I adalah:

1) Siswa masih kaku dengan pembelajaran dengan menggunakan model pembelajaran discovery learning dengan pendekatan saintifik, dengan menyampaikan langkahlangkah pembelajaran dengan jelas dan dapat diikuti dengan tepat.

2) Membagikan LKS minimal 3 LKS perkelompok atau perorang supaya siswa tidak bergiliran untuk membaca LKS tersebut sehingga siswa bebas menjawab soal tersebut dengan mandiri untuk didiskusikan dikelompoknya.

3) Meminta siswa yang kurang untuk menjelaskan pertanyaan temannya mengenai masalah yang ada pada LKS. Sehingga semua siswa aktif menanggapi jawaban siswa lain.

4) Menjelaskan kepada siswa bahwa soal-soal pada LKS merupakan soal yang memerlukan penalaran, sehingga memerlukan bacaan dan pemikiran tentang jawaban tersebut.

5) Guru harus lebih banyak memberikan penghargaan berupa pujian agar siswa termotivasi untuk lebih aktif dalam pembelajaran.

6) Mengelola waktu pembelajaran sebaik mungkin.

7) Mengurangi perilaku siswa yang tidak relevan dengan pembelajaran, contohnya: mengganggu kegiatan siswa lainnya, berdiam diri ditempat duduknya tanpa berupaya menyelesaikan tugas yang diberikan, keluar masuk ruangan kelas selama kegiatan pembelajaran berlangsung, melakukan kegiatan lain yang tidak terkait dengan tugas yang diberikan, dengan mengaktifkan siswa yang kurang mampu. 


\section{c. Siklus II}

Hasil observasi terhadap kemampuan guru dalam mengelola pembelajaran dengan model discovery learning dengan pendekatan saintifik pada materi trigonometri dengan sangat baik. Rata-rata aspek pada siklus II sebesar 4,66 dari skor ideal 5 dengan kategori sangat baik, sehingga aktivitas guru pada siklus II mengalami peningkatan dari siklus I.

Untuk hasil aktivitas siswa pada siklus II rata-rata nilainya 3,98 dari skor ideal 5 termasuk kategori baik, sehingga aktivitas siswa dalam pembelajaran model discovery learning dengan pendekatan saintifik pada materi trigonometri pada siklus II mengalami peningkatan dari siklus I.

Hasil pengolahan tes kemampuan penalaran matematika dari pembelajaran pada siklus II skor rata-rata kemampuan penalaran matematika sebesar 77,70 dari skor ideal 100 dengan simpangan baku 4,65 termasuk kategori tinggi, sehingga kemampuan penalaran matematika pada materi trigonometri mengalami peningkatan dari siklus I.

Berdasarkan hasil refleksi pada siklus I dengan beberapa revisi yang harus diperbaiki pada siklus II yang sudah mengalami peningkatan dalam aktivitas siswa dan aktivitas guru dalam pembelajaran model discovery learning dengan pendekatan saintifik pada materi trigonometri sehingga kemampuan penalaran matematika pada siswa kelas X - 7 SMA Negeri 11 Makassar dapat meningkat dari siklus sebelumnya.

Berdasarkan hasil analisis angket respons siswa, pada umumnya siswa memberikan respons positif terhadap pembelajaran melalui model pembelajaran discovery learning dengan pendekatan saintifik. Ada 4 item dengan 13 aspek yang direspons positif oleh siswa terhadap kegiatan pembelajaran. 


\section{E. KESIMPULAN DAN SARAN}

\section{Kesimpulan}

Kesimpulan dari hasil penelitian dan pembahasan adalah pembelajaran dengan model discovery learning dengan pendekatan saintifik yang telah dilaksanakan di kelas X-7 SMA Negeri 11 Makassar Tahun Pelajaran 2014-2015 dapat meningkatkan kemampuan penalaran matematika siswa. Hal ini ditunjukkan dengan pencapaian indikator-indikator sebagai berikut :

1. Proses pembelajaran pada penelitian ini sudah berjalan dengan baik ditandai dengan peningkatan pembelajaran dari pra tindakan sampai siklus II yaitu keaktifan siswa dalam pembelajaran pada siklus I dari enam kali pertemuan besarnya 2,99 berkategori cukup diatas indikator keberhasilan sebesar 2,5 dan pada siklus II dengan enam kali pertemuan besarnya 3,98 berkategori baik diatas indikator keberhasilan sebesar 2,5 sehingga mengalami peningkatan dari siklus I ke siklus II.

2. Hasil tes kemampuan penalaran matematika siswa pada pra tindakan sebesar 42,17, pada siklus I sebesar 70,23 dan pada siklus II besarnya menjadi 77,70 , sehingga kemampuan penalaran matematika mengalami peningkatan.

\section{Saran}

Berdasarkan pelaksanaan dan hasil penelitian tindakan kelas pada kelas X-7 SMA Negeri 11 Makassar Tahun Pelajaran 2014-2015, peneliti memberikan saran sebagai berikut :

1. Pembelajaran dengan model discovery learning dengan pendekatan saintifik perlu dilaksanakan oleh guru karena dengan model pembelajaran tersebut dapat melatih siswa dalam mengembangkan kemampuan penalaran matematikanya.

2. Dalam pembelajaran, guru dituntut untuk selalu kreatif dalam proses kegiatan belajar mengajar sehingga dapat memotivasi siswa untuk lebih semangat dalam mengikuti pembelajaran dan dalam pembelajaran terjadi variasi pembelajaran supaya siswa tidak bosan. 
3. Guru maupun calon peneliti diharapkan lebih kreatif dalam menyusun model pembelajaran yang mendukung peningkatan kemampuan penalaran matematika siswa.

\section{DAFTAR PUSTAKA}

Hosnan, Muhammad. 2014. Pendekatan Saintifik Dan Kontekstual Dalam Pembelajaran Abad 21. Ghalia Indonesia: Bogor

Hudaedah, Dodoh. 2014. Meningkatkan Kemampuan Penalaran Matematika Siswa Melalui Pembelajaran Kontekstual. Prosiding Seminar Nasional Pendidikan Matematika Program Pasca Sarjana. Bandung : STKIP Siliwangi

Kamus Besar Bahasa Indonesia. 2007. Jakarta:

Sani, R.A. 2014. Pembelajaran Saintifik untuk Implementasi Kurikulum 2013. Jakarta : Bumi Aksara

Soedjadi, R. 2007. Kiat Pendidikan Matematika di Indonesia.Jakarta: Direktorat Jenderal Tinggi Departemen pendidikan nasional

Wikipedia. 2013. Matemetika. (Online). (http://id.wikipedia.org/wiki/Matematika). Diakses: 22 Agustus 2014.

Wulandari, Enika. 2011. Meningkatkan Kemampuan Penalaran Matematis Siswa Melalui Pendekatan Problem Possing di Kelas VIII A SMP Negeri 2 Yogyakarta. Download: Diakses pada tanggal 4 Juli 2014

$\begin{array}{ll}\text { Nama } & \text { : Habriah Ahmad } \\ \text { Email } & \text { : habriah.ahmad@yahoo.com } \\ \text { Kontak person : } 085255020732\end{array}$

